\title{
Synthesis and Properties of Conjugated Copolymer Based on Poly( $p$-phenylenevinylene) Containing Tricarbonyl(arene)chromium and Thiophene Units in the Main Chain
}

\author{
Yasuhiro Morisaki, Hui CHEN, and Yoshiki CHUJO ${ }^{\dagger}$ \\ Department of Polymer Chemistry, Graduate School of Engineering, \\ Kyoto University, Yoshida, Sakyo-ku, Kyoto 606-8501, Japan
}

(Received January 14, 2003; Accepted March 19, 2003)

\begin{abstract}
A novel Poly( $p$-phenylenevinylene)-type (PPV-type) conjugated copolymer containing tricarbonyl(arene)chromium and thiophene units in the main chain was synthesized by Horner-Wadsworth-Emmons coupling reaction. The structure of the polymer was confirmed by ${ }^{1} \mathrm{H}$ NMR and IR. The polymer was soluble in common organic solvents. The polymer exhibited an absorption maximum at $454 \mathrm{~nm}$ in the $\mathrm{UV}$-vis absorption spectrum. The thermal stability and redox property of the polymer were studied in detail.

KEY WORDS Conjugated Polymer/ Tricarbonyl(arene)chromium / Thiophene Horner-

Wadsworth-Emmons Olefination / Poly ( $p$-phenylenevinylene) /
\end{abstract}

Considerable attention has been given to the synthesis of novel conjugated polymers due to their interesting electrical and optical properties. ${ }^{1}$ Since the first report on poly ( $p$-phenylenevinylene) (PPV) in 1990,2 PPVs and its derivatives have been the most extensively studied and have been used as light-emitting diodes (LEDs) for displays and other purposes. Polymers containing transition-metals are also of considerable importance, because of the requirements for advanced materials in molecular electronics, ${ }^{3}$ molecular optics, ${ }^{4}$ catalytic processes, ${ }^{5}$ and so on. A number of the well-defined conjugated polymers containing transition-metals $\pi$ coordinated to phenylene units in the polymer backbone have been synthesized. ${ }^{6}$

It is well-known that the tricarbonylchromium fragment, $\mathrm{Cr}(\mathrm{CO})_{3}$, is strongly electron-withdrawing and activates the $\eta^{6}$-arene ligand towards nucleophilic attack. ${ }^{7}$ Namely, since the electron density of arenes $\eta^{6}$ coordinated to a $\mathrm{Cr}(\mathrm{CO})_{3}$ unit is highly deficient, the tricarbonyl(arene)chromium, $\left(\eta^{6}\right.$-arene $) \mathrm{Cr}(\mathrm{CO})_{3}$, complex can act as an electron acceptor. In addition, the $\left(\eta^{6}\right.$-arene $) \mathrm{Cr}(\mathrm{CO})_{3}$ unit is attractive from the standpoints of redox activity, ${ }^{8}$ nonlinear optical properties, ${ }^{9}$ ligand exchange reactions, ${ }^{10}$ and catalytic applications. ${ }^{11}$ The preparation of a conjugated polymer containing a $\left(\eta^{6}\right.$-arene $) \mathrm{Cr}(\mathrm{CO})_{3}$ unit in the main chain as an intermolecular donor-acceptor system should be of great interest; however, little work has been carried out on the synthesis of such polymers so far. ${ }^{12}$ In addition, most of the $\left(\eta^{6}\right.$-arene $) \mathrm{Cr}(\mathrm{CO})_{3}$-containing polymers prepared to date are insoluble in common organic solvents, and their properties have not been studied in detail. Recently, we reported that the first soluble $\left(\eta^{6}\right.$-arene $) \mathrm{Cr}(\mathrm{CO})_{3}$-containing $\pi$-conjugated polymer $\mathbf{1}$ showed photoluminescence, redox activity, and conductivity. ${ }^{13}$ In this paper, the synthesis and properties of the PPV-type $\pi$-conjugated polymer containing $\left(\eta^{6}\right.$ arene $) \operatorname{Cr}(\mathrm{CO})_{3}$ and thiophene units in the main chain are described.

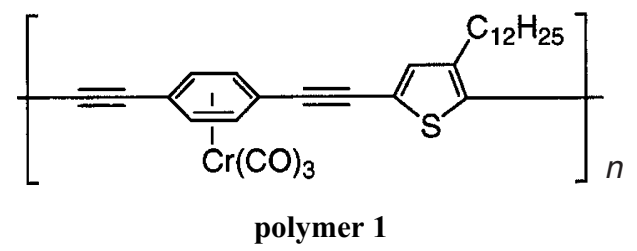

\section{EXPERIMENTAL}

General

${ }^{1} \mathrm{H}$ NMR spectra were recorded on a JEOL JNMEX270 instrument at $270 \mathrm{MHz}$. Samples were analyzed in $\mathrm{CDCl}_{3}$, and the chemical shift values were expressed relative to $\mathrm{Me}_{4} \mathrm{Si}$ as an internal standard. IR spectra were obtained on a PerkinElmer 1600 spectrometer. UV-Vis spectra were obtained on a JASCO V-530 spectrophotometer, and samples were analyzed in $\mathrm{CHCl}_{3}$ or in the film state at room temperature. Gel permeation chromatography (GPC) was carried out on a TOSOH UV-8011 and RI-8000 (Shodex K-803L column) using $\mathrm{CHCl}_{3}$ as an eluent after calibration with standard polystyrene. Thermogravimetric analysis

\footnotetext{
${ }^{\dagger}$ To whom correspondence should be addressed (Tel: +81-75-753-5655, Fax: +81-75-753-5675, E-mail: chujo@chujo.synchem.kyotou.ac.jp).
} 
<smiles>CCCc1cc(C=O)sc1C=O</smiles>

2<smiles>CCOP(=O)(Cc1ccc(CP(=O)(OCC)OCC)c(C=O)c1)OCC</smiles>

4

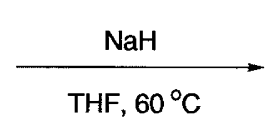

Scheme 1



5

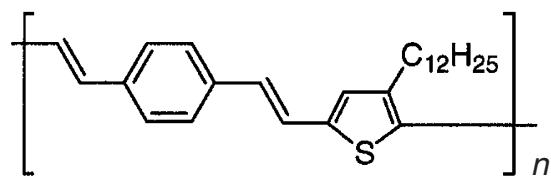

6

(TGA) was made on a Seiko EXSTAR 6000 instrument $\left(10^{\circ} \mathrm{C} \mathrm{min}{ }^{-1}\right)$. Cyclic voltammetry $(\mathrm{CV})$ was carried out with a BAS CV-50W Electrochemical Analyzer in $\mathrm{CH}_{2} \mathrm{Cl}_{2}$ solution of $0.1 \mathrm{M} \mathrm{Bu}^{n}{ }_{4} \mathrm{NPF}_{6}$ as a supporting electrolyte. Platinum wire auxiliary electrode and $\mathrm{Ag} / \mathrm{AgCl} \mathrm{RE}-5$ reference electrode were used in the $\mathrm{CV}$ measurement.

\section{Materials}

Tetrahydrofuran (THF) was distilled from sodium benzophenone ketyl under nitrogen. Sodium hydride (60\% dispersion in mineral oil), triethyl phosphite, hexacarbonylchromium, and $\alpha, \alpha$-dibromo- $p$-xylene were obtained commercially, and used without further purification. 2,5-Diformyl-3-dodecylthiophene $\mathbf{2}^{14}$ and tricarbonyl $\left\{\right.$ tetraethyl[ $\left(\eta^{6}-1,4\right.$-phenylene $)$ bis (methylene)]bis[phosphonate]\}chromium $\quad 4^{15}$ were prepared as described in the literature. All reactions were performed under a nitrogen atmosphere using a standard Schlenk technique.

\section{Polymerization}

A typical procedure is as follows. A $50 \mathrm{~mL}$ Pyrex flask was charged with $2(108 \mathrm{mg}, 0.35 \mathrm{mmol}), 4$ (180 mg, $0.35 \mathrm{mmol}), \mathrm{NaH}$ (30.8 mg, $0.77 \mathrm{mmol})$, THF $(5.0 \mathrm{~mL})$, and a stirring bar under a flow of nitrogen. The reaction was carried out at $60^{\circ} \mathrm{C}$ for $24 \mathrm{~h}$ with stirring under a nitrogen atmosphere. The reaction mixture was quenched with $1.0 \mathrm{M}$ hydrochloric acid after cooling to room temperature. The organic layer was separated and the aqueous layer was extracted with $\mathrm{CHCl}_{3}$. The combined organic layer was evaporated under vacuum and the residue was reprecipitated from a large amount of $\mathrm{MeOH}$ to give the corresponding polymer 5 as a red solid. The polymer $\mathbf{6}$ was also synthesized by the same procedure.

Polymer 5. Yield: $162 \mathrm{mg}, 90 \% . \quad{ }^{1} \mathrm{H}$ NMR $\left(270 \mathrm{MHz}, \mathrm{CDCl}_{3}\right): \delta 0.88(\mathrm{~m}, 3 \mathrm{H}), 1.26(\mathrm{~m}, 16 \mathrm{H})$, $1.59(\mathrm{~m}, 4 \mathrm{H}), 2.63(\mathrm{~m}, 2 \mathrm{H}), 5.60(\mathrm{~m}, 2.3 \mathrm{H}), 6.42(\mathrm{~m}$,
Table I. Results of Polycondensation ${ }^{\mathrm{a}}$

\begin{tabular}{ccccccc}
\hline Run & Monomer & Polymer & Yield $/ \%^{\mathrm{b}}$ & $M_{\mathrm{n}}{ }^{\mathrm{c}}$ & $M_{\mathrm{w}}{ }^{\mathrm{c}}$ & $M_{\mathrm{w}} / M_{\mathrm{n}}{ }^{\mathrm{c}}$ \\
\hline 1 & $\mathbf{2} / \mathbf{4}$ & $\mathbf{5}$ & 90 & 8000 & 9700 & 1.2 \\
2 & $\mathbf{2} / \mathbf{3}$ & $\mathbf{6}$ & 73 & 6400 & 8400 & 1.3 \\
\hline
\end{tabular}

${ }^{\mathrm{a}} \mathrm{A}$ mixture of $\mathbf{2}(0.35 \mathrm{mmol}), \mathbf{4}$ or $\mathbf{3}(0.35 \mathrm{mmol}), \mathrm{NaH}$ $(0.77 \mathrm{mmol})$, and THF $(5.0 \mathrm{~mL})$ in a $50 \mathrm{~mL}$ Pyrex flask was heated at $60^{\circ} \mathrm{C}$ for $24 \mathrm{~h}$ under a nitrogen atmosphere. ${ }^{\mathrm{b}}$ Isolated yields after reprecipitation into $\mathrm{MeOH}$. ${ }^{\mathrm{c}} \mathrm{GPC}\left(\mathrm{CHCl}_{3}\right)$, polystyrene standards.

$2 \mathrm{H}), 6.86(\mathrm{~m}, 2 \mathrm{H}), 7.13(\mathrm{~m}, 1 \mathrm{H}), 7.44(\mathrm{~m}, 1.7 \mathrm{H}) . \mathrm{IR}$ (KBr): 1960, 1887, $944 \mathrm{~cm}^{-1}$.

Polymer 6. $\quad$ Yield: $97 \mathrm{mg}, 73 \% . \quad{ }^{1} \mathrm{H}$ NMR $\left(270 \mathrm{MHz}, \mathrm{CDCl}_{3}\right): \delta 0.88(\mathrm{~m}, 3 \mathrm{H}), 1.26(\mathrm{~m}, 16 \mathrm{H})$, $1.62(\mathrm{~m}, 4 \mathrm{H}), 2.64(\mathrm{~m}, 2 \mathrm{H}), 6.83(\mathrm{~m}, 4 \mathrm{H}), 7.12(\mathrm{~m}$, $1 \mathrm{H}), 7.43$ (m, $4 \mathrm{H})$. IR (KBr): $942 \mathrm{~cm}^{-1}$.

\section{RESULTS AND DISCUSSION}

\section{Synthesis and Characterization of Polymers}

2,5-Diformyl-3-dodecylthiophene $\mathbf{2}^{14}$ and tricarbonyl \{tetraethyl[ $\left(\eta^{6}-1,4\right.$-phenylene)bis(methylene) $]$ bis [phosphonate] \}chromium $4^{15}$ were prepared according to published procedures. The procedure for the polymer synthesis by Horner-Wadsworth-Emmons olefination ${ }^{16}$ is outlined in Scheme 1, and the results are summarized in Table I. Treatment of 2 with $\mathbf{4}$ in the presence of $\mathrm{NaH}$ as a base at $60^{\circ} \mathrm{C}$ for $24 \mathrm{~h}$ under nitrogen produced the corresponding polymer $\mathbf{5}$ in $90 \%$ yield as a red solid after work-up. The polymer $\mathbf{5}$ was soluble in common organic solvents such as THF, $\mathrm{CHCl}_{3}$, and $\mathrm{CH}_{2} \mathrm{Cl}_{2}$ due to the alkyl substituent at the 3 -position of a thiophene ring. On the other hand, the reaction of 4 with 2,5-diformylthiophene resulted in an insoluble product. As a reference polymer, the polymer 6 was also obtained by the same method in 73\% yield. ${ }^{17}$ The number-average molecular weights of $\mathbf{5}$ and $\mathbf{6}$ were found by gel permeation chromatography (GPC) using polystyrene standards to be 8000 and 6700 , respectively, which correspond to degrees of polymerization of 16 and 18 . The ${ }^{1} \mathrm{H}$ NMR spectrum of the polymer $\mathbf{5}$ is shown in Figure 1. The peaks of phenyl protons coordinated to $\mathrm{Cr}(\mathrm{CO})_{3}$ appeared at $5.7 \mathrm{ppm}$. The peaks corresponding to olefinic protons were observed at 6.5 and $6.8 \mathrm{ppm}$. The peaks at around 




Figure 1. ${ }^{1} \mathrm{H}$ NMR spectrum of 5.

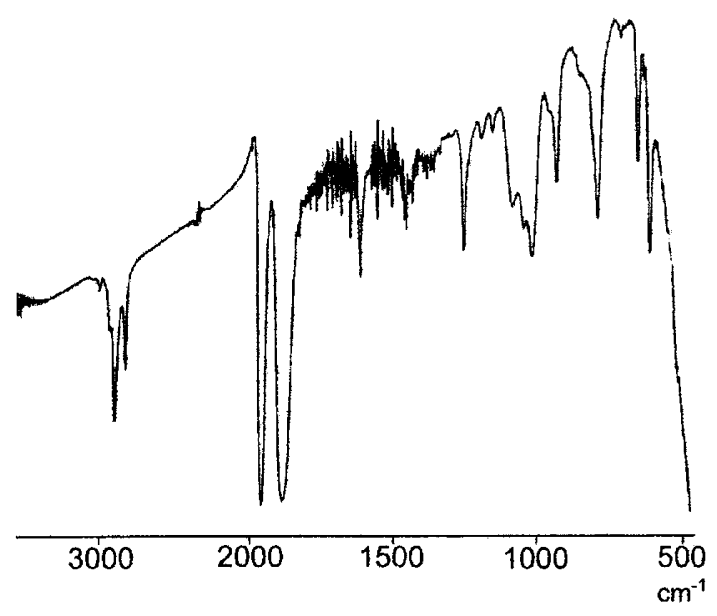

Figure 2. IR spectrum of $\mathbf{5}$.

7.0 ppm were derived from 4-position of a thiophene ring. Phenyl protons appeared at around $7.4 \mathrm{ppm}$ by thermal- or photo-dissociation of tricarbonylchromium moieties. Polymer 5 was found to consist of $65 \%$ chromium-coordinated phenylene and $35 \%$ phenylene moieties. The structures of the polymers obtained were confirmed by IR spectra. In Figure 2, the absorption of the out-of-plane bending mode of trans-vinylene appeared at $944 \mathrm{~cm}^{-1}$, and strong absorption of the stretching mode of coordinated carbon monoxide was observed at 1960 and $1887 \mathrm{~cm}^{-1}$.

\section{Optical Property}

The optical property of the polymers obtained was investigated by UV-vis absorption measurement in a $\mathrm{CHCl}_{3}$ solution at room temperature, and the spectra are shown in Figure 3. The absorption maxima corresponding to a $\pi-\pi^{*}$ transition in the polymer chain were observed at $454 \mathrm{~nm}\left(\varepsilon=1.8 \times 10^{4}\right)$ and $487 \mathrm{~nm}$ $\left(\varepsilon=3.1 \times 10^{4}\right)$ for 5 and $\mathbf{6}$, respectively. The absorption maximum of 5 was blue-shifted about $30 \mathrm{~nm}$ in comparison with that of $\mathbf{6}$. This result indicates that

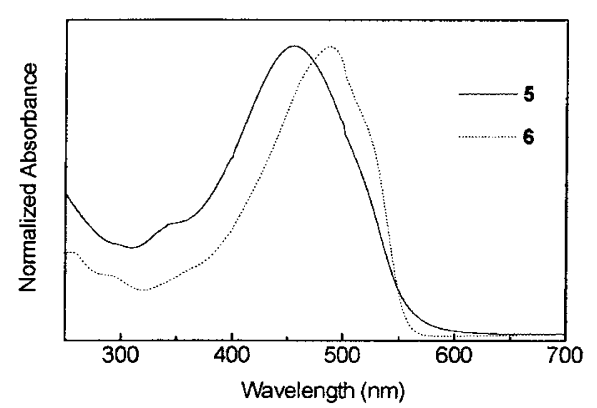

Figure 3. Absorption spectra of 5 and $\mathbf{6}$ in $\mathrm{CHCl}_{3}$.

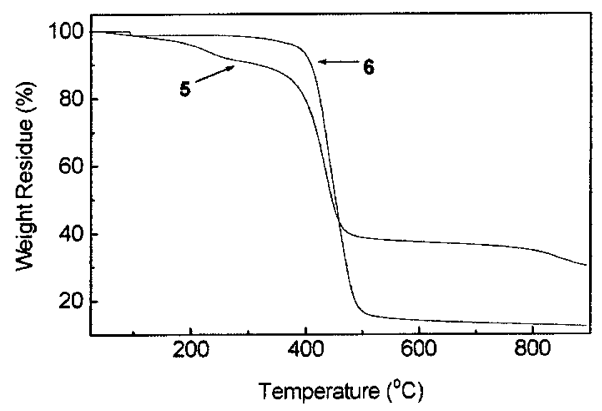

Figure 4. Thermogravimetric analysis (TGA) of $\mathbf{5}$ and $\mathbf{6}$ under nitrogen $\left(10^{\circ} \mathrm{C} \mathrm{min}^{-1}\right)$.

the polymer 5 containing coordinated $\mathrm{Cr}(\mathrm{CO})_{3}$ has a shorter conjugated length due to the steric hindrance of the $\mathrm{Cr}(\mathrm{CO})_{3}$ unit. $^{13}$ On the other hand, compared to the absorption maximum of the polymer $1\left(\lambda_{\max }=375 \mathrm{~nm}\right.$, $\left.\varepsilon=3.7 \times 10^{4}\right), \lambda_{\max }$ of $\mathbf{5}$ showed a red-shift of about $80 \mathrm{~nm}$. In addition, the UV-vis absorption spectra of the polymer films were also recorded. The absorption spectra of $\mathbf{5}$ and $\mathbf{6}$ in the solid state were slightly redshifted compared to those in solution, which indicates the rigidity of the polymer backbone resulted in no remarkable change between in the solid state and in solution.

\section{Thermal Property}

The measurement of thermogravimetric analysis (TGA) was also carried out for $\mathbf{5}$ and $\mathbf{6}$ under nitrogen (Figure 4). In the case of the polymer $\mathbf{5}$, the pyrolysis took place in two steps. The first step started at $210^{\circ} \mathrm{C}$, which could be attributed to the liberation of carbon monoxide coordinated to the chromium center; the second, which started at $370^{\circ} \mathrm{C}$, could be attributed to the decomposition of the polymer backbone. For the polymer 6, the decomposition also set in at $370^{\circ} \mathrm{C}$ and was complete at $420^{\circ} \mathrm{C}$.

\section{Electrochemical Property}

The electrochemical behavior of the polymer 5 was investigated by cyclic voltammetry. The measurement was performed in $0.1 \mathrm{M} \mathrm{Bu}_{4}{ }_{4} \mathrm{NPF}_{6}$ in dry $\mathrm{CH}_{2} \mathrm{Cl}_{2}$ at room temperature using a scan rate of $100 \mathrm{mV} \mathrm{s}^{-1}$. As 


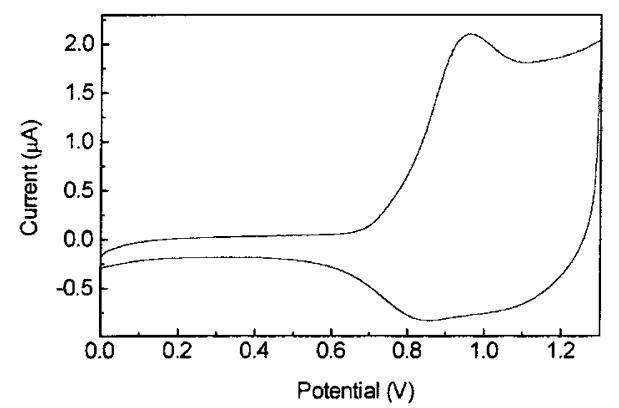

Figure 5. Cyclic voltammogram of 5 measured in $0.1 \mathrm{M}$ $\mathrm{CH}_{2} \mathrm{Cl}_{2}$ solution of $\mathrm{Bu}_{4}{ }_{4} \mathrm{NPF}_{6}$ using Pt electrode (vs. $\left.\mathrm{Ag} / \mathrm{Ag}^{+}\right)$at the sweep rate of $100 \mathrm{mV} \mathrm{s}^{-1}$.

shown in Figure 5, the polymer 5 exhibited a single broad oxidation peak at about $0.93 \mathrm{~V} v s$. $\mathrm{Ag} / \mathrm{Ag}^{+} \mathrm{re}-$ versibly, while no oxidation peaks appeared for the polymer $\mathbf{6}$ under the same condition. These results indicate that one electron oxidation process occurs on the $\left(\eta^{6}\right.$-arene $) \mathrm{Cr}(\mathrm{CO})_{3}$ moiety. The polymer 5 was electrochemically stable for repeated scanning in a solution. On the other hand, the film of 5 in $\mathrm{CH}_{3} \mathrm{CN}$ showed irreversible oxidation peak due to the ligand exchange reaction of (phenylene) $\mathrm{Cr}(\mathrm{CO})_{3}$ to $\left(\mathrm{CH}_{3} \mathrm{CN}\right)_{3} \mathrm{Cr}(\mathrm{CO})_{3} .{ }^{8 \mathrm{c}}$

\section{CONCLUSION}

Novel $\pi$-conjugated polymer containing $\left(\eta^{6}-\right.$ arene $) \mathrm{Cr}(\mathrm{CO})_{3}$ and thiophene units in the main chain based on PPV was synthesized by Horner-WadsworthEmmons olefination. The polymer was soluble in common organic solvents and characterized by NMR and IR spectra. The polymer 5 exhibited an absorption maximum at $454 \mathrm{~nm}$, which showed a red shift of about $80 \mathrm{~nm}$ compared to that of the polymer 1 reported in our previous work. The cyclic voltammogram showed a single oxidation peak for the $\left(\eta^{6}\right.$-arene $) \mathrm{Cr}(\mathrm{CO})_{3}$ unit reversibly. Further studies on the synthesis and properties of novel $\pi$-conjugated polymers possessing $\mathrm{a}\left(\eta^{6}\right.$-arene $) \mathrm{Cr}(\mathrm{CO})_{3}$ unit are now underway.

\section{REFERENCES}

1. a) U. H. F. Bunz, Chem. Rev., 100, 1605 (2000).

b) D. T. McQuade, A. E. Pullen, and T. M. Swager, Chem. Rev., 100, 2537 (2000).

c) A. Kraft, A. C. Grimsdale, and A. B. Holmes, Angew. Chem. Int. Ed., 37, 402 (1998).

d) T. A. Skotheim, R. L. Elsenbaumer, and J. R. Reynolds,
Eds., "Handbook of Conducting Polymers," 2nd ed., Marcel Dekker, New York, N.Y., 1998.

2. J. H. Burroughes, D. D. C. Bradley, A. R. Brown, R. N. Marks, K. Mackay, R. H. Friend, P. L. Burns, and A. B. Holmes, Nature, 347, 539 (1990).

3. B. Jiang, W. Y. Szu, S. L. Bailey, L. G. Hermans, R. A. Niver, M. A. Bolcar, and W. E. Jones Jr., Coord. Chem. Rev., 171, 365 (1998).

4. V. Balzani, A. Juris, M. Venturi, S. Campagna, and S. Serroni, Chem. Rev., 96, 759 (1996).

5. F. Ciardelli, E. Tsuchida, and D. Wohrle, Eds., "Macromolecule-Metal Complexes," Springer-Verlag GmbH \& Co., Berlin, 1996.

6. P. Nguyen, P. Gómez-Elipe, and I. Manners, Chem. Rev., 99, 1515 (1999).

7. a) R. Davis and L. A. P. Kane-Maguire, in "Comprehensive Organometallic Chemistry," G. Wilkinson, Ed., Pergamon Press, Oxford, 1982.

b) P. Collman, L. S. Hegedus, J. R. Norton, and R. G. Finke, "Principles and Applications of Organotransition Metal Chemistry," University Science Books, CA, 1987.

8. a) R. E. Dessy, F. E. Stary, R. B. King, and M. Waldrop, J. Am. Chem. Soc., 88, 471 (1966).

b) L. K. Yeung, J. E. Kim, Y. K. Chung, P. H. Rieger, and D. A. Sweigart, Organometallics, 15, 3891 (1996).

c) M. Morán, I. Cuadrado, M. C. Pascual, and C. M. Casado, Organometallics, 11, 1210 (1992).

9. T. J. J. Muller, A. Netz, M. Ansorge, E. Schmalzlin, C. Bräuchle, and K. Meerholz, Organometallics, 18, 5066 (1999).

10. E. A. K. Gustorf, L. H. G. Leeders, I. Fischler, and R. N. Perutz, Adv. Inorg. Chem. Radiochem., 19, 65 (1976).

11. J. H. Rigby, L. W. Mann, and B. J. Myers, Tetrahedron Lett., 42, 8773 (2001).

12. a) J. I. Jin and R. Kim, Polym. J., 19, 977 (1987).

b) M. E. Wright, Macromolecules, 22, 3256 (1989).

c) A. A. Dembek, R. R. Burch, and A. E. Feiring, J. Am. Chem. Soc., 115, 2087 (1993).

d) M. E. Wright and C. K. Lowe-Ma, Inorg. Chim. Acta., 232, 223 (1995).

13. a) Y. Morisaki, H. Chen, and Y. Chujo, Polym. Bull., 48, 243 (2002).

b) Y. Morisaki, H. Chen, and Y. Chujo, Polym. Bull., in press.

14. C. Amari, C. Pelizzi, G. Predieri, S. Destri, W. Porzio, H. Einsiedel, B. Menges, and S. Mittler-Neher, J. Mater. Chem., 6, 1319 (1996).

15. T. J. J. Muller, J. Organomet. Chem., 578, 95 (1999).

16. a) W. S. Wadsworth Jr., Org. React., 25, 73 (1977).

b) B. E. Maryanoff and A. B. Reitz, Chem. Rev., 89, 863 (1989).

17. H. K. Shim, T. Ahn, H. Y. Lee, and J. I. Lee, Korea Polym. J., 9, $116(2001)$. 